\title{
Meeting of the ESP Working Group History of Medicine and Pathology
}

\author{
Roland Sedivy
}

Published online: 7 August 2020

(C) Springer-Verlag GmbH Austria, ein Teil von Springer Nature 2020

In May/June 2019, we had the opportunity to organize the Sixth International Annual Meeting on History of Pathology and Medicine of the working group "History of Pathology" of the European Society of Pathology (Chair: Prof. Gabriella Nesi, Dept. of Pathology, University of Florence, Italy). It took place in the Pathological-Anatomical Collection of the Museum of Natural History Vienna that is located in the so-called Fool's Tower (Narrenturm; Fig. 1). With great pleasure and with help from Mr. Winter (custodian of the collection), we prepared the meeting with the topic "The roots of the Vienna Medical School. Influences from neighbouring countries and sciences", which finally comprised key lectures and free papers. This special issue of the $W M W$ presents quite a number of the given talks.

The meeting, however, was a bit overshadowed. Shortly before the meeting, our get together on the roof of the Museum of Natural History was cancelled. Then our chairwoman Prof. Nesi and I became ill, and Prof. van den Tweel kindly took responsibility for moderation of the meeting. Sadly, Prof. van den Tweel deceased in February 2020. The manuscript of his talk was completed and is published together with an obituary in this issue. A few months before this tragedy, another valued speaker, Prof. Szende, died surprisingly. We were thus all shocked. His obituary is also published herein. Our thoughts and hearts are with our deceased colleagues. In honour of Prof. van den Tweel and Prof. Szende, this special issue is dedicated to them.

Despite these adversities, the meeting was successful and very informative. Many colleagues from all over the world discussed vividly and exchanged their

Univ.-Prof. Dr. R. Sedivy, MLS ( $\bowtie)$

Sigmund Freud University, Faculty of Medicine, Vienna, Austria

roland@sedivy.net views. Fortunately, we were able to win a number of colleagues to provide their talk or another contribution to this special issue.

I am very grateful to Fabio Zampieri who presents the relevant interactions between Padua and Vienna and to Nadir Paksoy for describing the mutual influences between Turkey and Austria. The influence

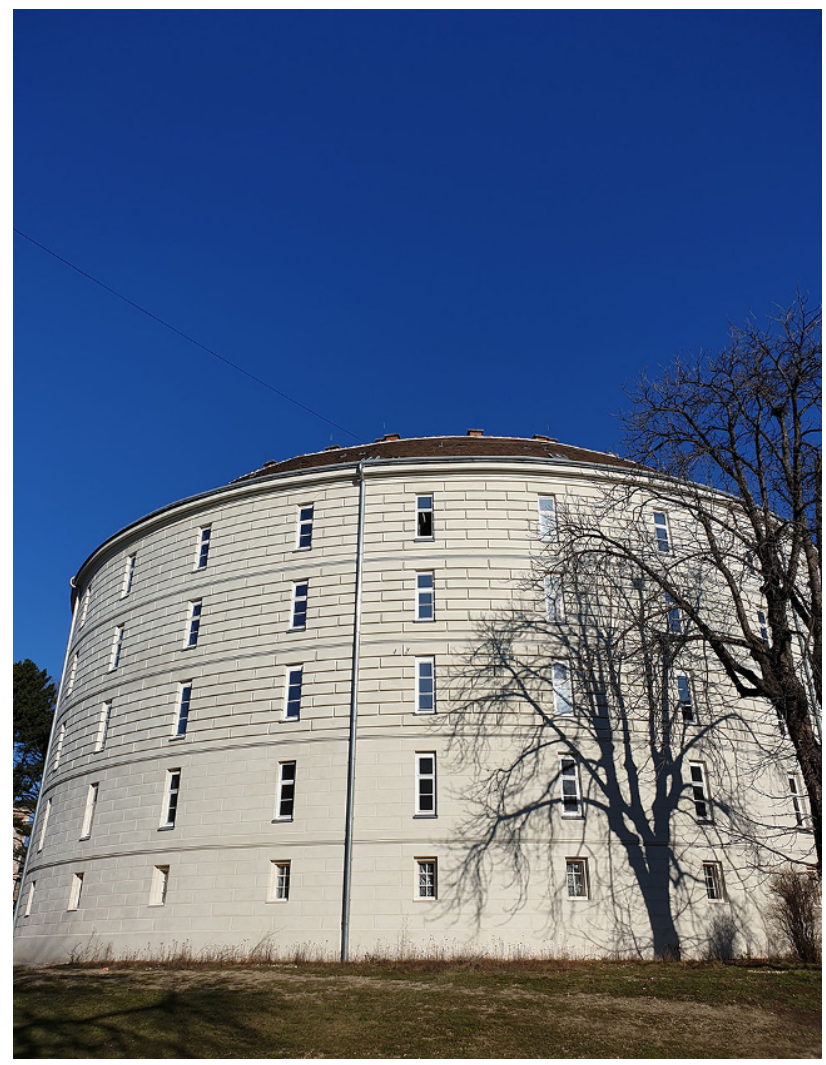

Fig. 1 The "Narrenturm" in Vienna that houses the Pathological-Anatomical Collection of the Museum of Natural History. (C Roland Sedivy) 


\section{editorial}

of Czech personalities is written by Ivo Steiner and the international relations of Carl Rokitansky are described by Mrs. Rokitansky. In addition, she gives new insights into the controversy between Rokitansky and Virchow.

Special thanks goes to Prof. Attila Zalatnai from the Semmelweis Medical University in Budapest for providing the obituary of Prof. Szende, who, together with Katalin Szabó, wrote a brilliant book about Hungarian physicians and their contributions that I recommend for further reading [1]. Further, Jan van den Tweel and his co-editors published a well-illustrated and comprehensive book about the history of pathology [2].

Special highlights are the articles by Sonia Schreiner about Semmelweis as a possible victim of harassment and by Christian Scatena about the wonderful anatomical models of Paolo Mascagni that were displayed in the Museum of History in the Josephinum in Vienna.

In addition, Robin van der Weiden became aware of a letter of Morgagni, which illustrates the international academic network of former times. Especially Haller was one of the great networkers of that time [3], and even with Morgagni, he had an intense exchange of letters [4].

Conflict of interest R. Sedivy declares that he has no competing interests.

\section{References}

1. Szende B, Szabó K. Aere perennius. More lasting than Bronze. Eponymous Hungarian physicians and their contributions and inventions. Budapest: Semmelweis Kiadó és MultimédiaStúdió; 2018.

2. Van den Tweel JG, Gu J, Taylor CR, editors. From magic to molecules: an illustrated history of disease. Peking: University Medical Press; 2016.

3. Sedivy R. Von Haller, Albrecht (1708-1777). In: van den Tweel JG, editor. Pioneers in Pathology. Cham: Springer; 2017.

4. Hintzsche E, editor. Haller, Albrecht von; Morgagni, Giambattista. Briefwechsel 1745-1768. Bern - Stuttgart: Huber; 1964.

Publisher's Note Springer Nature remains neutral with regard to jurisdictional claims in published maps and institutional affiliations. 